\title{
Impact of visual performance management systems on the performance management practices of organisations
}

\author{
Umit Bititci $^{1}$, Paola Cocca ${ }^{2 *}$, Aylin Ates ${ }^{3}$ \\ ${ }^{1}$ School of Management and Languages, Heriot Watt University, Edinburgh, \\ $U K ;^{2^{*}}$ Department of Mechanical and Industrial Engineering, University of Brescia, \\ Brescia, Italy; ${ }^{3}$ High Speed Sustainable Manufacturing Institute, London, UK \\ *Corresponding author: Via Branze 38, 25123 Brescia, Italy; telephone: \\ +390303715524; e-mail: paola.cocca@unibs.it
}




\title{
Impact of visual performance management systems on the performance management practices of organisations
}

\author{
The purpose of this paper is to explore how visual strategy and performance \\ management techniques impact performance measurement and management \\ practices of organisations. A novel visual performance management approach is \\ developed and implemented in qualitative case studies with seven manufacturing \\ SMEs across Europe. The implementation cases demonstrate that visual \\ management systems serve to support ongoing strategy development and \\ implementation, facilitate performance measurement and review, enable people \\ engagement, improve internal and external communication, enhance \\ collaboration and integration, support the development of a continuous \\ improvement culture and foster innovation. Additional explorative and \\ longitudinal research is required to understand the long term impact of such \\ approaches in both small and larger organisations.
}

Keywords: performance management; visualisation; strategy; visual management

\section{Introduction}

Both academics and practitioners recognise the need for today's contemporary management practices to move towards more open and inclusive management practices to create organisations that are truly fit for the future (Johnson and Broms 2000; Ghoshal 2005). Hamel (2009) led a group of scholars and CEOs and proposed a road map for reinventing management, identifying 25 management's grand challenges. According to their view, managers need the ability to build a culture of mutual respect and collaboration in order to engage everyone in the idea generation and strategic thinking process. They suggest that organisations must create a 'democracy of information' where employees at all levels of the organisation are informed and empowered so they can feel engaged and act intelligently in the interest of the entire enterprise. 
This paper attempts to respond to this challenge by exploring, through an inductive qualitative study, how visual strategy and performance management approaches impact upon the performance measurement and management practices of organisations, contributing to the recent debate in the International Journal of Production Research (Jaca et al. 2014).

The point of departure for this paper is that visual management techniques, commonly used in operations and lean management, are rarely used for strategic management purposes. The use of visual methods in modern management is largely rooted in the Toyota production system and Lean Management theory (Tezel, Koskela, and Tzortzopoulos 2009; Murata and Katayama 2010, 2013; Pavnaskar, Gershenson, and Jambekar 2003). Particularly, the 5S technique represents the pillars for the creation of a visual workplace, where everything is visible enough so that anyone in the organisation must be able to quickly and easily understand what is happening (Hiroyuki 1995). This type of approach has proven effective as a communication method mainly at an operational shop floor level (Parry and Turner 2006; Bilalis et al. 2002). However, found that adoption of visual management tools appears to be limited (Jaca et al. 2014; Lengler and Eppler 2007) with some examples being employed at different stages of the performance management process (Whittington 1996; Mills et al. 1998a; Jack 2002; Bürgi and Roos 2003; Liff and Posey 2004; Platts and Tan 2004; Parry and Turner 2006; Eppler and Platts 2009; Phaal and Muller 2009). To date relatively little has been written about visual management, so organisations have not had a clear process and methodology to help them understand how to implement it and which benefits they may expect to achieve (Liff and Posey 2004).

In order to provide new insights towards the research gap identified above, this article investigates the following research question: 'How do end-to-end visual strategy 
and performance management approaches impact upon the performance measurement and management practices of organisations?'. In pursuit of this aim, the paper first develops, through explorative action research, an end-to-end approach to visual management. The development of the visual management approach in seven manufacturing enterprises is described. The findings of the research are discussed in some detail leading to the conclusion.

\section{Background}

It is a commonly accepted fact that strategy management and performance measurement are closely related. In managing the performance of an organisation, strategic aims and objectives are deployed to value streams, processes, teams and individuals through performance measures and progress against various improvement and growth actions is reviewed through a continuous process (Kaplan and Norton 1992; Lebas 1995; Otley 1999; Bititci, Turner, and Begemann 2000; Busi and Bititci 2006; Stiffler 2006). To this end, the background literature pertinent to the objectives of this paper is presented under headings: performance measurement and management, strategy management and visualisation.

\subsection{Performance measurement and management}

In the last 30 years, the focus in the organisational performance field has shifted from performance measurement (i.e. what to measure, how to measure and how to report the results) to performance management (i.e. how to use the measures to manage the performance of the organisation) (Amaratunga and Baldry 2002; Neely 2005; Folan and Browne 2005; Bititci et al. 2011).

For the purpose of this paper, performance management is considered as 'the iterative closed-loop process in which performance measures are used to manage and 
improve organisational performance through continuous adaptation to the changing operating environment' (adapted from Bititci, Carrie, and McDevitt 1997, and Otley 1999). According to literature, the performance management process starts with strategy development which consists in the definition of vision, mission and values and the identification of strategic objectives, followed by the development of specific action plans to achieve those objectives (Bititci, Carrie, and McDevitt 1997; Otley 1999; Pope 2004; Busi and Bititci 2006; Armstrong 2009). Then, the planned actions are implemented (Verweire and Van Den Berghe 2004; Eckerson 2010) and the progress of these actions and the achievement of the objectives are monitored (Lebas 1995; Busi and Bititci 2006; Stiffler 2006; Radnor and Barnes 2007; Parthiban and Goh 2011). Regular performance and strategy reviews ensure that the planned improvement and growth actions are delivering intended outcomes and that the strategy adopted is delivering the organisational objectives. It is noted that these reviews should be event based rather than calendar based, to be able to adapt to the changes in the organisations operating environment. When the strategy changes, the performance measures are reviewed in order to keep them relevant and aligned to the company's objectives (Busi and Bititci 2006; Parthiban and Goh 2011). Using appropriate and effective communication means is considered particularly vital in order to create commitment towards achieving goals and promote appropriate behaviours (Otley 1999; Verweire and Van Den Berghe 2004; Barnes and Radnor 2008).

\subsection{Strategy management}

The theory of strategy management has evolved from rational planned view through emergent view, to process and practice view (Porter 1980; Mintzberg 1978; Van de Ven 1992; Whittington et al. 2006). The main premise of strategy process research is that strategy has both planned and emergent dynamics and is rarely implemented as planned. 
Rather, strategy emerges as a result of managerial thinking, acting and reflecting through formal and informal interactions between managers (meetings, conversations, memos, e-mails, etc). However, the process by which these strategic decisions and actions are captured and communicated is considered critical for maintaining alignment with the organisational purpose (Teece 1990; Pettigrew 1992) and that this process can be planned/predefined (Mintzberg and Quinn 1992; Mills et al. 1998b; Chakravarthy and White 2001).

Motivated with this line of thinking, we have started to see early examples of visual approaches to strategy management. For example, Strategy Canvas (Kim and Mauborgne 2002) allows an organisation to visualise the competitive dynamics of its operating environment. Strategy maps enable financial goals and objectives to be linked with customer, internal processes and learning and growth objectives and measures (Kaplan and Norton 1996, 2000). Hoshin Kanri Planning (Witcher and Butterworth 2001) using spreadsheets deploys top goals to functions, teams and processes. Also BAE Systems use artists' illustrations (paintings) displayed on the shop floor to initiate visual dialogue resulting in $28 \%$ increase in employees' understanding of the company's strategy ${ }^{1}$.

\subsection{Visualisation}

Visualisation concerns the representation of data, information and knowledge in a graphic format which is conducive to acquiring insights, creating a vivid picture, developing an elaborate understanding or communicating experiences (Lenger and Eppler 2007). The literature on visual communication comes from a variety of disciplines, including: Artificial intelligence, graphic design, marketing, performance

\footnotetext{
${ }^{1}$ See: http://www.youtube.com/watch?v=xYdeDQG5EqU
} 
measurement, cognitive ergonomics, cognitive psychology, communications, education and process mapping (Wickes 2005).

The advantages of visual representations are well acknowledged in literature. Research by Mayer (2001) found that by adding visuals to words learning improved by $23 \%$ and transfer of learning by $89 \%$. Maltz (2000) highlighted that communication supported with tables, graphs and visual means improves perceived information quality. Similarly, Eppler and Platts (2009) identify three main types of benefits: cognitive, social and emotional. Among the cognitive benefits they list: facilitating elicitation and synthesis of information, enabling new perspectives to allow better, more exhaustive comparisons and facilitating easier recall and sequencing. As social benefits they suggest: integrating different perspectives, assisting mutual understanding and supporting coordination between people; and finally the emotional benefits include creating involvement and engagement, providing inspiration and providing convincing communication. According to Tezel, Koskela, and Tzortzopoulos (2009), the use of visual tools in a work environment improves transparency, facilitates routine job tasks, enables on-the-job training, influences people's behaviours, fosters continuous improvement, creates shared ownership, supports management by facts, avoids information deficiencies or information overload and removes organisational boundaries. Greif (1991) points out that the essential principle of visual communication is sharing of information which translates into sharing of power, control and responsibility, thus enhancing support, acceptance and motivation.

However, visual methods are not risk-free approaches and an adequate understanding of the possible risks and limitations connected to visualisation is necessary to avoid pitfalls (Jarvenpaa and Dickson 1988; Tversky 2005; Bresciani and Eppler 2009). The main risk is the possible misinterpretation of graphic representations 
(Bresciani and Eppler 2009). Other risks concern the acceptance of visual information by managers and employees (Meyer 1997). Thus, the design phase is considered critical for overcoming possible visualisation risks, and guidelines available in literature provide useful advice towards designing effective visual communication systems (e.g.: Tufte 1983; Jarvenpaa and Dickson 1988; Ware 2004; Few 2006; Eppler and Burkhard 2007).

\title{
2.4. Visual approaches for performance management
}

According to Liff and Posey (2004):

\begin{abstract}
Visual performance management is a system for organisational improvement that focuses on what is important to improve performance. It adds a new dimension to the processes, systems, and structures that make up the existing organisation by utilising strong graphic visualisation techniques to heighten its focus on sustaining competitive advantage.
\end{abstract}

The literature provides only a few examples of visual tools employed at different stages of the performance management process. The majority of the papers focus on the strategy development phase. Mills et al. (1998a) propose the use of 'strategy charts' for the representation of manufacturing strategy. The chart contains objectives, decisions and events which are connected by arrows to show causal relationships. A similar approach is proposed by Kaplan and Norton (2000) with their 'strategy map'. Strategy maps clarify cause-and-effect relationships between actions and objectives along the four perspectives of the Balanced Scorecard (BSC): financial, customer, internal processes and learning and growth. The use of Roadmaps as a visual technique to support strategic planning is suggested by Phaal and Muller (2009), while Platts and Tan (2004) recommend performance profiling, strategy charting and TAPS (Tool for Action Plan Selection). Bürgi and Roos (2003) move beyond visual tools and propose 
multimodal experiences of creating three-dimensional representations of strategy to improve people's understanding of the organisation. Eppler and Platts (2009) illustrate five case studies to examine how different types of visualisation techniques (strategy charting, parameter ruler, TAPS, synergy map, BSC tree) can provide benefits within the four stages of the strategy process - analysis, development, planning and implementation. Suzaki (1993) recommends, as part of his 'Glass Wall Management', the use of six categories of visual aids to foster open communication on the shop floor. On the basis of three case studies from aerospace companies, Parry and Turner (2006) propose guidelines for the implementation of visual control boards to develop dynamic measurement systems, while Jack (2002) presents an IT-based Value Mapping solution, which uses visual pictorial maps to integrate and represent the performance measures useful for value creation.

It is clear that the use of visual aids in management is not new. However, majority of the tools are focused on providing localised solutions with no consistent and integrated coverage of the end-to-end managerial process. Visual management techniques used for operational purposes appear to be more interactive when compared to their strategic counterparts. Visual approaches to strategy appear somewhat static as they are mainly used for top-down communication rather than engaging and involving everyone in the strategic conversation and letting strategy and actions emerge from that conversation. Literature implies that there are benefits to be had from visual management techniques that integrate strategic and operational perspectives that engage people in a conversation on the strategy and performance of the organisation. The conceptual model depicted in Figure 1 summarises these implications.

(Figure 1) 


\section{Methodology}

\subsection{The research process}

The visual management approach described in the paper emerged as a result of an explorative action research (Eden and Huxham 1996; Barratt, Choi, and Li 2011; McCutcheon and Meredith 1993), conducted in seven manufacturing SMEs across Europe. Action research is an inductive approach and it refers to the involvement of researchers as co-practitioners in the organisation where the research is made over a matter which is of genuine concern for the organisation's members (Eden and Huxham 1996). The research was developed through a cyclical four-step process of design, implementation, evaluation and refinement of a visual performance management system (VPMS) in the companies which were all project partners in a European project. The steps of the research process are shown in Figure 2.

(Figure 2)

During a workshop organised by the research team with the senior management from all the companies the main findings from the literature (above) were outlined providing the basis for development of the of the VPMS concept. The result of the workshop was the definition of a set of high level guidelines VPMS. Subsequently, each company used these guidelines to design their own VPMS, integrating and modifying existing systems, with support and facilitation from the research team. The main principle was to allow each company to customise the approach and adapt it to its own needs and culture. Every six months the implementations were reviewed and refined in discussions between the researchers and the management teams, both independently in each company and during review meetings with all project partners. Four reviews were carried out over a two year period (2011 and 2012) providing sufficient time for the processes to embed and lessons to emerge. The cyclical reviews of the implemented 
systems and the discussions with the management teams led to a refined version of the approach initially developed which is described in the next section.

Table 1 below summarises the research methodology adopted.

(Table 1)

Data was collected through a rigorous case study protocol (Barratt, Choi, and Li

2011). The research team used multiple data sources such as plant tours, several face-to-

face and online meetings, company documents, processes maps, and organisational

charts in order to achieve triangulation of data. Case study protocols used in semi-

structured interviews were updated based on emerging data and observations regarding

visual management system implementations (Eden and Huxham 1996). Based on the

methodological suggestions by Barratt, Choi, and Li (2011), initially the researchers

analysed each case individually followed by a cross case analysis.

First, the performance measurement and management practices of each

company before and after VPMS implementation was documented, as summarised in

Table 3 . Then, the text was content analysed independently by two researchers to

identify the categories of impacts connected to VPMS implementation. The researchers

compared their lists of categories and reconciled any differences to obtain a

consolidated set of impacts that was used for final coding of the content of the table. In

the end, the identified impacts and their relationships were summarised in an influence

map (Figure 11). For example, the impacts described in the text 'there is a clearer and

more purposeful process for strategic communication that is facilitating discussion on

how to achieve business goals, thus enabling everyone to participate in defining the

business milestones' were coded as 'Improve communication and discussion', 'Share

strategic information with everyone ' and 'Staff empowerment', and contributed to a part

of the influence map as shown in Figure 3.

http://mc.manuscriptcentral.com/tprs Email: ijpr@tandf.co.uk 


\section{(Figure 3)}

\subsection{Overview of the emerging visual management approach}

Many of the companies already had some form of visual management system in the operational parts of their business (i.e. electronic boards, production boards, problem solving boards, lean management boards), thus they already had some former experience of visual management. But none of the organisations had previously attempted to use visual methods for strategic management. Therefore, the initial challenge was to develop a visual approach to strategic management and then integrate and deploy this through the operations of the organisation.

The resulting visual management system is based on the integration of existing visual management approaches at strategic and operational levels, including messaging boards, strategy maps, policy deployment and SWOT analysis and competitive analysis. It comprises of two levels and two themes that lead to four different types of visual management boards that are linked to one another (Table 2).

(Table 2)

The emerging visual management approach is meant to be flexible and provide general guidelines and examples allowing each application to be tailored to the requirements, preferences and culture of the organisation.

\section{Strategic planning boards}

The aim of the strategic planning board is to engage everyone in the strategic conversation and assist with the development, deployment and review of the strategic objectives of the organisation. It comprises of five areas: 
- Guiding Vision, serves to provide a constant reminder of organisation's purpose in the form of vision, mission and values.

- Horizon Scanning, serves to capture pertinent developments in the operating environment and prompt for further discussion.

- Constantly updated SWOT area, in line with the changing business environment

- Performance Analysis area, where the current state of the business is summarised from different perspectives (financial, market dynamics, product lifecycle; internal and customer facing KPIs).

- Strategy Map, linking high-level goals to specific actions.

The board is intended to be used through regular reviews where the content of the horizon scanning part is reviewed for significant threats and opportunities in the context of the performance analysis area that leads to identification of actions that link to high level goals and objectives in the strategy map area.

Strategic progress boards

The role of this board is to provide a means to monitor the progress of the strategic actions, and to challenge strategic assumptions when actions do not lead to the expected results. The board comprises of four areas:

- Guiding Vision, a reminder to inspire decisions aligned with the vision, mission and values of the company.

- Business as usual area showing the effects of the implemented actions on the organisation's performance.

- Projects area, where the progress and results of each project from the strategy map are displayed. 
- Communication area, intended to record notes, problems and suggestions related to the strategic projects.

The strategic progress board is related to the strategic planning board and it enables the organisation to recognise trends and re-align its targets and strategies. The performance data recorded on the board are regularly updated at management meetings held around the board (typically weekly) using the board to drive the agenda of the meeting.

\section{Operational planning boards}

The purpose of the operational planning board is to engage employees in the process of deploying strategy down the organisation and converting strategic objectives into operational goals. According to the company's structure and needs, there may be only one planning board for the whole organisation or one for each operational unit, be it a plant, department or team. It should show how the specific plant, department or team that owns the board plans to contribute to the achievement of the objectives set in the strategy planning board. The aim is to encourage employees' participation in the definition of operational objectives and actions so that each employee feels both empowered and responsible towards meeting those goals. The board should clarify how goals and actions at an operational level tie together and lead to the attainment of strategic objectives.

\section{Operational progress boards}

The role of the operational progress board is to provide the people working in the specific operational unit that owns that board with a visual cockpit containing all the data needed to self-manage and monitor the progress towards the achievement of the 
objectives set in the operational planning board. The board has the same structure of the strategic progress board and supports the monitoring of the KPIs and projects of the specific operational unit using control charts.

These four boards replicate and integrate the functions of purpose and vision statements, horizon scanning, competitive analysis, SWOT analysis, strategy maps and Hoshin Kanri planning like policy deployment in to an integrated and simple to follow framework.

\section{Case studies and findings}

The VPMS approach described above was implemented in seven case studies. In the following paragraphs we provide two representative but contrasting examples and summarise the findings from all seven cases.

\subsection{Bottling Ltd}

Bottling Ltd. is a medium-sized enterprise operating in a B2B environment and characterised by a lower level of maturity of management processes and organisational culture. It offers co-packing and contract bottling services to the Scottish whisky industry. It operates in a highly competitive market and differentiates itself by forming close relationships with its customers and offering a highly flexible and responsive service. It employs 64 people.

Visual boards were created with the management team and reviewed every six months in collaboration with the research team. The input data required to develop the visual boards is extracted from the companies stand-alone spreadsheets. This data was used to update visual boards manually. The VPMS did not have any impact on the 
functionality of the companies ITC systems as VPMS was intended to be used to enable

\section{interactive communication.}

Figure 4 shows the final version of the strategic planning board from Bottling Ltd.

(Figure 4)

Financial performance figures are provided, while non-financial KPIs are qualitatively assessed through a benchmarking exercise with competitors' performance. Traffic light colours are used to highlight critical performance areas where improvement is required. The projects currently in progress are highlighted in a different colour and when the projects are completed they are ticked on the board.

In order to monitor their strategic progress a strategic progress board was developed (Figure 5). In the 'Business as usual' area the trend of each KPI is shown by a graph. Traffic lights are intended to facilitate interpretation and alert users to the state of particular measures. In the 'Project area' a table provides an overview of the projects that are in progress.

(Figure 5)

Bottling Ltd decided not to implement any operational planning board. Since the hierarchical structure of the company is quite flat, they preferred to include operational objectives and actions directly in the strategic planning board. However, they did develop an operational progress board to provide the shop floor with information useful to self-manage their activity (Figure 6). Bottling Ltd decided to include in the board a section to provide information about customer complaints. The idea is to make the people on the shop floor aware of the consequences of their performance on customer service and engage them in learning as well as identification and implementation of corrective actions.

(Figure 6) 


\subsection{Entertainment Ltd}

Entertainment Ltd is a medium-sized enterprise operating in a B2C environment and characterised by more advanced managerial practices. It is a family owned and managed business which designs and manufactures high-end home entertainment systems. The company employs 160 staff.

The visual strategy exercise with the entire senior management team resulted in a strategic planning board (Figure 7) and a strategic progress board (Figure 8) which focused on achieving key milestones over a two year period.

(Figure 7)

The horizon scanning process is supported by means of an internal competition. Everyone inside the firm is encouraged to report any news that may be relevant for the company's business environment. A dedicated e-mail account has been set up to collect all the contributions and every month the person who has provided the most useful piece of information is awarded a prize. In the Performance Analysis area the current value of each KPI is shown along with a performance target. Entertainment Ltd decided to develop a strategic plan setting milestones for every six months. Each milestone contributes to achieving one or more of the company's goals, requiring the definition of a series of strategic initiatives/projects with clear ownership, deadlines and deliverables.

(Figure 8)

The strategic progress board does not make use of graphs, but of grid type tables. The main KPIs are grouped in tables according to flow of business, i.e. from marketing and sales through procurement and manufacturing to customer service and company financial results, where updates are recorded and discussed at daily meetings. Majority of the VSM data was extracted from the company's sophisticated Oracle-based purpose build ICT system. All managers bring print outs for the performance metrics 
and results related to their area of responsibilities. Then, they manually transfer this

high level information on the grid type white boards on the wall. Based on this the

visual boards are used to facilitate daily management meetings. The project section lists

the milestones identified in the strategic planning board and provides details about

initiatives, goals and timing, using colours to highlight potential problems with the

progress of different strategic initiatives.

Having embedded the visual management practice at the strategic level, the operations group developed its own mission and guiding principles (Figure 9) where the corporate objectives identified in the strategic planning board have been translated into operational objectives and KPIs to monitor the performance of the department.

(Figure 9)

Figure 10 illustrates the operational progress board developed by the operations group. Similarly to the progress board implemented at the strategic level, performance data are mainly summarised in tables with projects and corrective actions being located on the right-hand side of the board and highlighted in red.

(Figure 10)

\section{Findings}

Table 3 presents an overview of the findings from all seven case study companies. For each company the table provides performance measurement and management practices before and after VPMS implementation, and assesses its business impact.

(Table 3)

Table 4 provides a cross case analysis, showing the impacts of VPMS implementation per single company.

\section{(Table 4)}




\section{Discussion}

Two types of reactions were observed when the research team first proposed the companies to design and implement a visual management system. Five companies out of seven were immediately enthusiastic about the new approach and willing to test it. The remaining two companies were at first quite sceptical about the visual approach that emerged from the initial developments. Their main concern was about having to share strategic information with a wider group then the core management/family team. Both companies were family businesses characterised by a command and control type of managerial style and a hierarchical managerial culture based on decisions being taken in a 'top-down' approach. In these two companies a two-step implementation approach was adopted. First, only a few tools were used with the senior managers, such as SWOT analysis and strategy maps. This, together with seeing examples and benefits gained from other companies, made the owner-managers become more confident about the potentials of the whole approach and gradually started a process of cultural change that eventually led to the implementation of a complete visual management system.

Ostensibly it can be claimed that VPMS has positive impact on the performance or potential performance of all companies. Whilst some of the impact was incremental, such as more focused improvement projects resulting in incremental productivity improvement, others were more transformational, such as diversification in to new markets. However, whatever the scope and scale of the business impact, VPMS appears to achieve this through clearer, more focused and more interactive communication of organisational objectives and priorities. In short it seems to engage people at all levels in a conversation about the strategy and performance of the company.

According to the feedback collected regarding strategy planning and implementation, the visual approach has provided valuable support in the iterative process of defining and refining company's objectives, structuring them into a formal 
strategy. In accordance to Eppler and Platts (2009), the companies experienced some of the main cognitive benefits of visual representation. Indeed, they find the VPMS useful to 'clarify the link between improvement projects and business goals' and 'represent and put in order the elements and ideas that a company has in mind'. The system acted as 'a glue', facilitating the integration of several improvement projects in one overall picture. The milestones approach has been particularly appreciated by the companies, since it makes 'everyone understands why a product or system or innovation has come along and importantly what they need to do to be part of that'. Another manager added: 'Vision statement has become clearer and accessible for employees. It is now an achievable target for staff'. The companies recognised that the milestones set in the strategic planning board act as 'a strategy agenda for management team meetings for reviews and planning' and provide a common purpose for the whole business, thus aligning people's behaviours to the strategy of the company. 'Organising the whole company on milestone delivery fosters strategy implementation' and facilitates both short and long term planning. Also, the progress boards 'support the planning and delivery of projects'.

Performance measurement and review processes were also improved by the visual approach. The boards provided support in the identification of the relevant KPIs, leading to the adoption of more balanced performance measurement systems. They acted as 'a constant reminder to check progress and results' and 'excellent starting point for periodical performance review'.

Similarly to what advocated by Liff and Posey (2004), the managers recognised the need to use a structured end-to-end approach able to guide the company along the whole performance management process. One manager remarked: 


\begin{abstract}
The process gets you thinking in a different way. [...] We always thought we were good at strategy, but the new approach showed us that there was a much better way of doing it, that was more systematic and succinct. There's nothing new in the underlying principles, but the approach is much more structured which gives us more confidence in the robustness of the outputs. The most revolutionary aspect however, is that putting it on a whiteboard and making it alive, visual expression of the plans for the business, turns it into something tangible and dynamic, rather than a static document that is written by an individual, filed and forgotten. Everyone involved in the process feels like it is their strategy and can clearly see how it fits into what actions they are working towards.
\end{abstract}

Confirming Eppler and Platts (2009) and Greif (1991), the visual boards had positive emotional impact on the companies, in particular in terms of people engagement: 'What has also been amazing is that everyone in the whole company has been involved to some degree; there is real excitement in the company, people are taking responsibility for every aspect of the milestone, everyone feels part of it and can be really proud of what they are achieving'.

Based on this feedback it could be argued that, the VPMS is perfectly in line with the call by Hamel (2009) for more open and inclusive management practices to create organisations truly fit for the future.

The VPMS benefited the case study companies also from the social point of view, similarly to the findings by Tezel, Koskela, and Tzortzopoulos (2009) and Eppler and Platts (2009). Indeed, the visual approach facilitated the coordination and integration among different units and hierarchical levels, thus enabling the delegation of responsibilities. It helped 'getting the management team to work more as a unit rather than as individuals'. The owner manager of one company commented:

The company benefitted greatly from the visual strategy approach which encouraged coordination and integration between departments and the management team. [...] Shop floor staff is more engaged with the management, who feel free to 
provide new ideas and discuss any problems without any fear. [...] The method established a 'Thinking together-Acting together' approach in our company which was completely new in a traditional family owned SME like us.

In line with Eppler and Platts (2009), the system succeeded in improving both internal and external communication. The companies found it 'useful for explaining aspects of the business to customers and other stakeholders'. The system helped sharing strategic type of information with everyone, thus 'establishing a common understanding in the company', as advocated by Armstrong (2009). One manager commented: 'By visually displaying milestones on a board and using this to communicate them to the workforce, we were able to bring them to life and embed the messages into the thinking of everyone involved'.

Finally, confirming the results by Tezel, Koskela, and Tzortzopoulos (2009), the visual management system has proven effective in fostering cultural change, 'building $a$ continuous improvement culture' and promoting the adoption of more participative practices, thus enabling 'the generation of great ideas that contribute to the company' and enhancing innovation process. The owner of one company stated:

\footnotetext{
The visual management methodology is an extremely powerful tool to help change mind-sets towards thinking about responsiveness. [...] It has helped our company undergo a complete cultural transformation in the way in which we plan for the future and monitor how the business is performing.
}

The influence map in Figure 11 summarises how the VPMS has impacted the practices of the case study organisations.

(Figure 11)

\section{Conclusion}

This research contributed to theory and practice by clarifying that end-to-end visual 
strategy and performance management approaches are effective in: supporting ongoing strategy development and implementation; facilitating performance measurement and review; improving internal and external communication; enabling people engagement in the strategic thinking process; enhancing collaboration and integration among different units and levels; supporting cultural changes and fostering innovation.

A limitation of this study is that the 'voice of the operator' in terms of workers' opinions about the implemented visual management system has not been directly investigated. Rather, the managers gathered the reactions inside the company and based on their interpretations, they provided feedback to the researchers. Therefore, further research is required to directly assess operators' point of view, thus avoiding possible bias of people from middle or senior management.

Additional implementations are required for an evaluation of the methodology in large organisation. Possible problems that may arise in large enterprise settings would deal, for example, with the need of board duplication to ensure visibility from all the areas of the company. In such a case it may be worth investigating the opportunities offered by electronic displays to solve replication and consistency issues while allowing real-time contributions by everyone.

Successful long term implementation of a visual management system requires an appropriate organisational culture. Therefore, longevity of the tool and embedding of this approach in the organisation should be investigated through further longitudinal research.

\section{Acknowledgements}

This work was supported by the European Commission under Grant NMP2-LA-2008-214657. 


\section{References}

Ackermann, F., C. Eden, and I. Brown. 2005. The Practice of Making Strategy: A Stepby Step Guide. London: Sage.

Amaratunga, D., and D. Baldry. 2002. "Moving from Performance Measurement to Performance Management." Facilities 20 (5-6): 217-223. doi:

$10.1108 / 02632770210426701$.

Armstrong, M. 2009. Armstrong's Handbook of Human Resource Management Practice (11th ed.). London: Kogan Page.

Barnes, D., and Z. Radnor. 2008. "Performance Measurement and Performance Management: The Operations Management Perspective." In Performance Management: Multidisciplinary Perspectives, edited by Thorpe, R., and J. Holloway, 89-106. Basingstoke: Palgrave Macmillan.

Barratt, M., T. Y. Choi, and M. Li. 2011. "Qualitative Case Studies in Operations Management: Trends, Research Outcomes and Future Research Implications." Journal of Operations Management 29: 329-342. doi: 10.1016/j.jom.2010.06.002.

Bilalis, N., G. Scroubelos, A. Antoniadis, D. Emiris, and D. Koulouriotis. 2002. "Visual Factory: Basic Principles and the 'Zoning' Approach." International Journal of Production Research 40 (15): 3575-3588. doi: 10.1080/00207540210140031.

Bititci, U., F. Ackermann, A. Ates, J. Davies, P. Garengo, S. Gibb, J. MacBryde et al. 2011. "Managerial Processes: Business Process that Sustain Performance." International Journal of Operations \& Production Management 31 (8): 851887. doi: 10.1108/01443571111153076.

Bititci, U. S., A. S. Carrie, and L. McDevitt. 1997. "Integrated Performance Measurement Systems: A Development Guide." International Journal of Operations \& Production Management 17 (5): 522-534. doi: 10.1108/01443579710167230.

Bititci, U. S., T. Turner, and C. Begemann. 2000. "Dynamics of Performance Measurement Systems." International Journal of Operations \& Production Management 20 (6): 692-704. doi: 10.1108/01443570010321676.

Bresciani, S., and M. J. Eppler. 2009. "The Risks of Visualization: A Classification of Disadvantages Associated with Graphic Representations of Information." In 
Identität und Vielfalt der Kommunikations-wissenschaf, edited by Schulz, P. J., U. Hartung, and S. Keller. Konstanz: UVK Verlagsgesellschaft mbH.

Bürgi, P., and J. Roos. 2003. "Images of Strategy." European Management Journal 21

(1): 69-78. doi: 10.1016/S0263-2373(02)00153-6.

Busi, M., and U. S. Bititci. 2006. "Collaborative Performance Management: Present Gaps and Future Research." International Journal of Productivity and Performance Management 55 (1): 7-25. doi: 10.1108/17410400610635471.

Chakravarthy, B. S., and R. E. White. 2001. "Strategy Process: Forming, Implementing and Changing Strategies." In Handbook of Strategy and Management, edited by Pettigrew, A., H. Thomas, and R. Whittington, 182-206. London: Sage. doi: 10.4135/9781848608313.n9.

Eckerson, W. W. 2010. Performance Dashboards: Measuring, Monitoring and Managing Your Business. Hoboken: John Wiley \& Sons.

Eden, C., and C. Huxham. 1996. “Action Research for Management Research.” British Journal of Management 7: 75-86. doi: 10.1111/j.1467-8551.1996.tb00107.x.

Eppler, M. J., and R. A. Burkhard. 2007. "Visual Representation in Knowledge Management: Framework and Cases." Journal of knowledge management 11 (4): 112-122. doi: 10.1108/13673270710762756.

Eppler, M. J., and K. W. Platts. 2009. "Visual Strategizing. The Systematic Use of Visualization in the Strategic-Planning Process." Long Range Planning 42: 4274. doi: 10.1016/j.lrp.2008.11.005.

Few, S. 2006. Information Dashboard Design. The Effective Visual Communication of Data. Sebastopol: O’Reilly Media.

Folan, P., and J. Browne. 2005. "A Review of Performance Measurement: Towards Performance Management." Computers in Industry 56: 663-680. doi: 10.1016/j.compind.2005.03.001.

Ghoshal, S. 2005. "Bad Management Theories Are Destroying Good Management Practices." Academy of Management Learning and Education 4 (1): 75-91. doi: 10.5465/AMLE.2005.16132558.

Greif, M. 1991. The Visual Factory. Building Participation through Shared Information. Boca Raton: CRC Press.

Hamel, G. 2009. "Moon Shots for Management." Harvard Business Review 87 (2): $91-$ 98. doi: 10.1225/R0902H. 
Hiroyuki, H. 1995. Five Pillars of the Visual Workplace. Reprint, New York: Productivity Press.

Jaca, C., E. Viles, D. Jurburg, and M. Tanco. 2014. "Do Companies with Greater Deployment of Participation Systems Use Visual Management More Extensively? An Exploratory Study.” International Journal of Production Research 52 (6): 1755-1770. doi: 10.1080/00207543.2013.848482.

Jack, A. 2002. "Value Mapping - A Second Generation Performance Measurement and Performance Management Solution." Paper presented at the Third International Conference on Theory and Practice in Performance Measurement, Boston, July 17-19.

Jarvenpaa, S. L., and G. W. Dickson. 1988. "Graphics and Managerial Decision Making: Research-Based Guidelines." Communications of the ACM 31 (6): 764774. doi: $10.1145 / 62959.62971$.

Johnson, H. T., and A. Broms. 2000. Profit Beyond Measure: Extraordinary Results through Attention to Work and People. Englewood Cliffs, NJ: Prentice Hall. Johnson, G., L. Melin, and R. Whittington. 2003. "Micro Strategy and Strategizing: Towards an Activity-Based View." The Journal of Management Studies 40 (1): 3-22. doi: 10.1111/1467-6486.t01-2-00002.

Kaplan, R. S., and D. P. Norton. 1992, Jan-Feb. "The Balanced Scorecard - Measures that Drive Performance." Harvard Business Review 78 (5): 70-79.

Kaplan, R. S., and D. P. Norton. 2000, Sep-Oct. "Having Trouble with Your Strategy? Then Map It", Harvard Business Review 78 (5): 167-76. doi: 10.1225/5165.

Kim, W. C., and R. Mauborgne. 2002, Jun. "Charting Your Company's Future." Harvard Business Review 80 (6): 76-83. doi: 10.1225/R0206D.

Lebas, M. J. 1995. "Performance Measurement and Performance Management." International Journal of Production Economics 41 (1-3): 23-35. doi: 10.1016/0925-5273(95)00081-X.

Lengler, R., and M. Eppler. 2007. "Towards a Periodic Table of Visualization Methods for Management." In Proceedings of the IASTED International Conference on Graphics and Visualization in Engineering (GVE'07), edited by Alam, M., 8388. Anaheim, CA: ACTA Press.

Liff, S., and P. A. Posey. 2004. Seeing Is Believing: How the New Art of Visual Management Can Boost Performance Throughout Your Organization. New York: AMACOM. 
Maltz, E. 2000. "Is All Communication Created Equal? An Investigation into the Effects of Communication Mode on Perceived Information Quality (PIQ)." Journal of Product Innovation Management 17: 110-127. doi: 10.1016/S07376782(99)00030-2.

Mayer, R. E. 2001. Multimedia Learning. Cambridge, UK: Cambridge University Press. Meyer, J-A. 1997. "The Acceptance of Visual Information in Management." Information \& Management 32 (6): 275-287. doi: 10.1016/S03787206(97)00032-3.

McCutcheon, D. M., and J. R. Meredith. 1993. "Conducting Case Study Research in Operations Management.” Journal of Operations Management 11 (3): 239-256. doi: 10.1016/0272-6963(93)90002-7.

Mills, J., A. Neely, K. Platts, and M. Gregory. 1998a. "Manufacturing Strategy: A Pictorial Representation." International Journal of Operations \& Production Management 18 (11): 1067-1085. doi: 10.1108/01443579810231660.

Mills, J., A. Neely, K. Platts, H. Richards, and M. Gregory. 1998b. "The Manufacturing Strategy Process: Incorporating a Learning Perspective." Integrated Manufacturing Systems 9 (3): 148-155. doi: 10.1108/09576069810210330.

Mintzberg, H. 1978. "Patterns in Strategy Formation. Management Science 24 (9): 934948. doi: $10.1287 / \mathrm{mnsc}$.24.9.934.

Mintzberg, H., and J. B. Quinn. 1992. The Strategy Process: Concepts and Contexts. New Jersey: Prentice-Hall.

Morgan, J. M., and J. K. Liker. 2006. The Toyota Product Development System. Integrating People, Process and Technology. New York: Productivity Press.

Murata, K., and H. Katayama. 2010. "A Study on Construction of a Kaizen Case-Base and Its Utilisation: A Case of Visual Management in Fabrication and Assembly Shop-Floors.” International Journal of Production Research 48 (24): 7265 7287. doi: 10.1080/00207540903373823.

Murata, K., and H. Katayama. 2013. "A Study of the Performance Evaluation of the Visual Management Case-Base: Development of an Integrated Model by Quantification Theory Category III and AHP.” International Journal of Production Research 51 (2): 380-394. doi: 10.1080/00207543.2011.638944.

Nag, R., D. C. Hambrick, and M. J. Chen. 2007. "What is Strategic Management, Really? Inductive Derivation of a Consensus Definition of the Field." Strategic Management Journal 28 (9): 935-955. doi: 10.1002/smj.615. 
Neely, A. 2005. "The Evolution of Performance Measurement Research Developments in the Last Decade and a Research Agenda for the Next." International Journal of Operations \& Production Management 25 (12): 12641277. doi: 10.1108/01443570510633648.

Neely, A., C. Adams, and M. Kennerley. 2002. The Performance Prism: The Scorecard for Measuring and Managing Business Success. London: FT Prentice Hall.

Otley, D. 1999. "Performance Management: A Framework for Management Control Systems Research." Management Accounting Research 10 (4): 363-382. doi: 10.1006/mare.1999.0115.

Parry, G. C., and C. E. Turner. 2006. "Application of Lean Visual Process Management Tools." Production Planning \& Control 17 (1): 77-86. doi:

10.1080/09537280500414991.

Parthiban, P., and M. Goh. 2011. "An Integrated Model for Performance Management of Manufacturing Units." Benchmarking: An International Journal 18 (2): 261281. doi: 10.1108/14635771111121702.

Pavnaskar, S. J., J. K. Gershenson, and A. B. Jambekar. 2003. "Classification scheme for lean manufacturing tools." International Journal of Production Research 41 (13): 3075-3090. doi: 10.1080/0020754021000049817.

Pettigrew, A. 1992. "The Character and Significance of Strategy Process Research." Strategic Management Journal 13 (S2): 5-16. doi: 10.1002/smj.4250130903.

Phaal, R., and G. Muller. 2009. "An Architectural Framework for Roadmapping: Towards Visual Strategy." Technological Forecasting \& Social Change 76: 3949. doi: 10.1016/j.techfore.2008.03.018.

Platts, K., and K. H. Tan. 2004. "Strategy Visualisation: Knowing, Understanding and Formulating." Management Decision 42 (5): 667-676. doi: 10.1108/00251740410538505.

Pope, E. C. 2004. HR How-to: Performance Management. Chicago: CCH.

Porter, M. E. 1980. Competitive Strategy Techniques for Analyzing Industries and Competitors. New York: The Free Press.

Radnor, Z. J., and D. Barnes. 2007. "Historical Analysis of Performance Measurement and Management in Operations Management." International Journal of Productivity and Performance Management 56 (5/6): 384-396. doi: 10.1108/17410400710757105. 
Stiffler, M. A. 2006. Performance: Creating the Performance-Driven Organization. New York: John Wiley \& Sons.

Suzaki, K. 1993. The New Shop Floor Management: Empowering People for Continuous Improvement. New York: Free Press.

Teece, D. J. 1990. "Contributions and Impediments of Economic Analysis to the Study of Strategic Management." In Perspectives on Strategic Management, edited by Fredrickson, J. W., 39-80. New York: Harper Business.

Teece, D. J., G. Pisano, and A. Shuen. 1997. "Dynamic Capabilities and Strategic Management." Strategic Management Journal 18 (7): 509-533. doi: 10.1002/(SICI)1097-0266(199708)18:7<509::AID-SMJ882>3.0.CO;2-Z.

Tezel, B. A., L. J. Koskela, and P. Tzortzopoulos. 2009. "The Functions of Visual Management." Paper presented at the $6^{\text {th }}$ International Research Symposium, Salford, UK, January 27-28.

Tufte, E. R. 1983. The Visual Display of Quantitative Information. Cheshire: Graphics Press.

Tversky, B. 2005. "Visuospatial Reasoning." In The Cambridge Handbook of Thinking and Reasoning Cambridge, edited by K. Holyoak, and Morrison, R. G., 209240. Cambridge, UK: Cambridge University Press.

Van de Ven, A. H. 1992. "Suggestions for Studying Strategy Process: A Research Note." Strategic Management Journal 13 (S1): 169-188. doi: 10.1002/smj.4250131013.

Verweire, K., and L. Van Den Berghe. 2004. Integrated Performance Management: A Guide to Strategy Implementation. London: Sage.

Ware, C. 2004. Information Visualization: Perception for Design. 2nd ed. San Francisco: Morgan Kaufmann.

Whittington, R. 1996. "Strategy as Practice." Long Range Planning 29 (5): 731-736. doi: 10.1016/0024-6301(96)00068-4.

Whittington, R., E. Molloy, M. Mayer, and A. Smith. 2006. "Practices of Strategising/ Organising. Broadening Strategy Work and Skills." Long Range Planning 39 (6): 615-629. doi: 10.1016/j.lrp.2006.10.004.

Wickes, M. J. 2005. “An Exploratory Study into the Design and Use of Visual Reporting System in Project and Programme Management Environments", $\mathrm{PhD}$ diss., Cranfield University. 
Witcher, B. J., and R. Butterworth. 2001. "Hoshin Kanri: Policy Management in Japanese-Owned UK Subsidiaries." Journal of Management Studies 38 (5): 651674. doi: 10.1111/1467-6486.00253.

1

2

3

4

5

6

7

10

11

12

13

14

15

16

17

18

19

20

21

22

23

24

25

26

27

28

29

30

31

32

33

34

35

36

37

38

39

40

41

42

43

44

45

46

47

48

49

50

51

52

53

54

55

56

57

58

59

60

http://mc.manuscriptcentral.com/tprs Email: ijpr@tandf.co.uk 
Table 1: Research methodology.

\begin{tabular}{|l|l|}
\hline Research Question & $\begin{array}{l}\text { How do end-to-end visual strategy and performance management } \\
\text { approaches impact upon the performance measurement and } \\
\text { management practices of organisations? }\end{array}$ \\
\hline $\begin{array}{l}\text { Research approach } \\
\text { and justification }\end{array}$ & $\begin{array}{l}\text { Inductive approach aiming to build theory, because there is not } \\
\text { sufficient theory informing the research question. Most theories } \\
\text { focus on the impact of visual tools on operational aspects of the } \\
\text { business such as lean implementations or on a single strategic } \\
\text { management process. }\end{array}$ \\
\hline Research method & $\begin{array}{l}\text { Action research with seven companies implementing visual } \\
\text { management systems over a two-year period. }\end{array}$ \\
\hline $\begin{array}{l}\text { Triangulation and } \\
\text { reliability }\end{array}$ & $\begin{array}{l}\text { Working with the management teams to develop and refine visual } \\
\text { management system approaches based on a framework deduced } \\
\text { from the findings of the literature. Multiple data sources used to } \\
\text { achieve triangulation of data. Tools and case study protocols used } \\
\text { in semi-structured interviews updated based on emerging data and } \\
\text { observations. }\end{array}$ \\
\hline Sampling strategy & Self selected by companies participating in an EU project. \\
\hline Unit of analysis & Manufacturing SMEs \\
\hline Number of cases & $\begin{array}{l}7 \text { SMEs - 3 from Turkey, 1 from Ireland, 1 from Poland and 2 } \\
\text { from United Kingdom. } \\
\text { with data collection. }\end{array}$ \\
\hline analysis & andative data analysis through within case analysis followed by \\
\hline
\end{tabular}


1

2

3

4

5

6

7

8

9

10

11

12

13

14

15

16

17

18

19

20

21

22

23

24

25

26

27

28

29

30

31

32

33

34

35

36

37

38

39

40

41

42

43

44

45

46

47

48

49

50

51

52

53

54

55

56

57

58

59

60

Table 2: Structure of the visual performance management system.

\begin{tabular}{|c|c|c|}
\hline Level & Planning & Progress \\
\hline Strategic & $\begin{array}{c}\text { Strategic planning } \\
\text { board }\end{array}$ & $\begin{array}{c}\text { Strategic progress } \\
\text { board }\end{array}$ \\
\hline Operational & $\begin{array}{c}\text { Operational } \\
\text { planning board }\end{array}$ & $\begin{array}{c}\text { Operational } \\
\text { progress board }\end{array}$ \\
\hline
\end{tabular}


Table 3: Overview of the seven case studies.

\begin{tabular}{|c|c|c|c|c|c|}
\hline 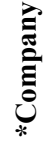 & 总 & 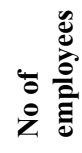 & Pre-VPMS implementation & Post-VPMS implementation & Business Impact \\
\hline 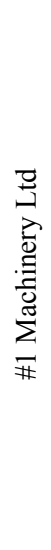 & 胥 & 7 & $\begin{array}{l}\text { - No formal strategy and it is based on the owner's mental model } \\
\text { and priorities that can change quite regularly. } \\
\text { - No formal performance measures or reviews except the usual } \\
\text { financial metrics centred on sales and profitability. } \\
\text { - Regular communication between the Owner/Managing Director } \\
\text { (MD) and management team but there is no real sense of strategid } \\
\text { purpose and direction apart from 'sell more' and 'spend as little } \\
\text { as possible'. Rest of the communications is focused around } \\
\text { operational matters responding to past events, customers' } \\
\text { demands, enquiries and problems. }\end{array}$ & $\begin{array}{l}\text { - In constructing the VPMS the company developed a survival plan } \\
\text { around new business opportunities with the VPMS creating a focus on } \\
\text { the company priorities. } \\
\text { - A more mature and balanced set of KPIs was introduced that included } \\
\text { customer facing measures as well as indicators that enabled monitoring } \\
\text { of progress with respect to the new business opportunities. } \\
\text { - The VPMS centred on a strategic planning and operational progress } \\
\text { board acted as the constant reminder of company priorities as well as } \\
\text { providing the agenda items for discussing at weekly staff meetings. } \\
\text { - Weekly staff meetings, conducted in front of the visual management } \\
\text { boards, were used to catch up and discuss both strategic and } \\
\text { operational matters. As a consequence the Owner/MD is able to } \\
\text { delegate operational decisions to his first line manager and spend more } \\
\text { time on pursuing the new business opportunities. This also enabled him } \\
\text { to elicit help from various staff on strategic matters as appropriate. }\end{array}$ & $\begin{array}{l}\text { With the global recession (2008- } \\
2010) \text { the company was struggling } \\
\text { to survive. } \\
\text { Implementation of VPMS led to } \\
\text { identification of business } \\
\text { opportunities in new markets. } \\
\text { In } 2012 \text { the company diversified in } \\
\text { to renewable energy markets and } \\
\text { started to grow. }\end{array}$ \\
\hline
\end{tabular}




\begin{tabular}{|c|c|c|c|c|c|}
\hline & 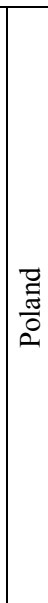 & 160 & $\begin{array}{l}\text { - The company has a clear strategy for becoming the market leader } \\
\text { in remanufactured ink cartridge sector in its target markets. The } \\
\text { MD has an MBA and has developed a structured and top-down } \\
\text { strategy management process based on balanced scorecard and } \\
\text { policy deployment approaches. } \\
\text { - There are spreadsheets with KPIs for the whole organisation and } \\
\text { each key function. Progress and performance against targets are } \\
\text { reviewed through regular appraisals. } \\
\text { - Despite the sophisticated strategy management and deployment } \\
\text { process, the management team remains unhappy with the } \\
\text { process' ability to respond to changes throughout the planning } \\
\text { cycle (yearly). } \\
\text { - The link between strategic priorities and lean based improvement } \\
\text { projects in manufacturing operations are unclear. } \\
\text { - There is a top down management style where employees are not } \\
\text { involved in strategy. }\end{array}$ & $\begin{array}{l}\text { - The company felt that they had a well-developed and robust strategy } \\
\text { and performance planning and management process, which took them } \\
\text { a few years to implement. As a result, they decided not to deploy } \\
\text { strategic planning boards. However, the company was more interested } \\
\text { in how to control the progress and KPIs in an effective way. } \\
\text { - The updated operational planning and control boards provide much } \\
\text { clearer links between strategic priorities and operational KPIs and } \\
\text { initiatives. } \\
\text { - People at operational levels understand how shop floor improvement } \\
\text { projects are aligned with the company's vision and strategic direction. } \\
\text { This has led to some innovations emerging from first line managers } \\
\text { and operational teams. }\end{array}$ & $\begin{array}{l}\text { Incremental improvement of } \\
\text { productivity mainly facilitated by: } \\
\text { - better informed operational staff; } \\
\text { - better alignment of improvement } \\
\text { projects with company goals; } \\
\text { - innovations emerging from } \\
\text { ground up. }\end{array}$ \\
\hline & $\breve{b}$ & 64 & $\begin{array}{l}\text { - The company has a formal strategy based around growing its } \\
\text { customer base. } \\
\text { - Operations Director/MD leads company based on direction from } \\
\text { management board. Weekly management meetings are held to } \\
\text { discuss current issues, but strategy and strategic decisions are not } \\
\text { systematically shared in these meetings. } \\
\text { - There are strategic performance measures largely focused on } \\
\text { financial indicators and sales. } \\
\text { - There are no mechanisms, visual or otherwise, for sharing } \\
\text { company's objectives, strategy and performance measures with } \\
\text { the rest of the management team and employees. } \\
\text { - Operationally the company has adopted certain aspects of lean } \\
\text { manufacturing with some notice boards in the manufacturing area } \\
\text { that contain information on key initiatives, e.g. set up reduction, } \\
\text { but these are not explicitly or implicitly related to strategic } \\
\text { objectives and measures. } \\
\text { - There is an informal and participative management style with } \\
\text { regular conversations between management and the rest of the } \\
\text { workforce, but most of this dialogue remains operational. }\end{array}$ & $\begin{array}{l}\text { - Company's objective, strategy and key performance indicators are } \\
\text { explicitly displayed in the strategic planning board. } \\
\text { - KPIs include customer facing metrics e.g. on-time delivery and lead- } \\
\text { times as well as internal facing metrics such as OEE. } \\
\text { - Weekly management meetings are held in front of the boards using the } \\
\text { information to review progress and performance. } \\
\text { - Operational progress board explicitly links strategic objectives to } \\
\text { operational objectives, measures and improvement initiatives, enabling } \\
\text { a common understanding of the business priorities and the } \\
\text { development of shared action plans at all levels of the organisation. } \\
\text { - Line managers and operational staff use the progress board to have } \\
\text { daily review of performance and progress of improvement projects } \\
\text { where employees are more participative in discussions concerning } \\
\text { operational issues with ideas on improvement regularly emerging } \\
\text { bottom-up. }\end{array}$ & $\begin{array}{l}\text { Significant improvement in } \\
\text { productivity resulted in attracting } \\
\text { more work/orders from key } \\
\text { customers. Also customers } \\
\text { invested in introduction of new } \\
\text { technologies in the production } \\
\text { lines. } \\
\text { The productivity improvements } \\
\text { were facilitated by: } \\
\text { - better strategic focus; } \\
\text { - better informed staff at all levels; } \\
\text { - better alignment of improvement } \\
\text { projects with company goals; } \\
\text { - improvement emerging from } \\
\text { bottom-up. }\end{array}$ \\
\hline
\end{tabular}




\begin{tabular}{|c|c|c|c|c|c|}
\hline 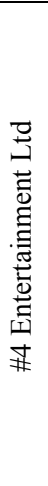 & $\breve{b}$ & 160 & $\begin{array}{l}\text { - Company has very clear but short term strategy based around } \\
\text { growth that is widely communicated to people at all levels } \\
\text { through regular management briefings (monthly town-hall } \\
\text { meetings) but not through formal documentation. } \\
\text { - The strategic KPIs are designed around the sales management } \\
\text { pipeline and reviewed by the management team on a daily basis } \\
\text { with operational staff present at the meeting as required. } \\
\text { - At operational level, the company has visual boards in key } \\
\text { locations giving pertinent information on performance and } \\
\text { progress of key initiatives. } \\
\text { - In general people at all levels understand short term objectives } \\
\text { and priorities but remain unsure about long term plans. }\end{array}$ & $\begin{array}{l}\text { - A visual strategic planning board is now in place that outlines } \\
\text { company's development ambitions in six monthly milestones. } \\
\text { - The visual strategic planning board is used at the board level in } \\
\text { quarterly meetings to review the milestones. It is also used to deploy } \\
\text { strategy across all levels in monthly strategy meetings with the } \\
\text { management team. } \\
\text { - Operational planning boards are used to link strategic objectives and } \\
\text { milestones to operational areas of the business making the existing } \\
\text { operational progress boards more relevant and meaningful. } \\
\text { - There is a clearer and more purposeful process for strategic } \\
\text { communication that is facilitating discussion on how to achieve } \\
\text { business goals, thus enabling everyone to participate in defining the } \\
\text { business milestones and review actions and progress. }\end{array}$ & $\begin{array}{l}\text { The milestone approach enabled } \\
\text { the company to make significant } \\
\text { checks of progress every six } \\
\text { months. These milestones resulted } \\
\text { in development of new products } \\
\text { and enhancement of existing } \\
\text { products. In August } 2014 \text { the } \\
\text { company reported record sales and } \\
\text { profits. }\end{array}$ \\
\hline 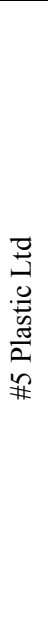 & 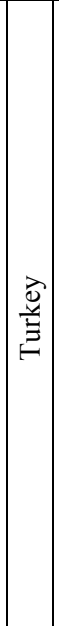 & 79 & $\begin{array}{l}\text { - Strategic planning and implementation processes are informal in } \\
\text { this family owned small company. } \\
\text { - Performance management and control is based on financial and } \\
\text { productivity related KPIs. } \\
\text { - Strategic communications are mainly done through the } \\
\text { manufacturing supervisor/ foreman. There is a missing link } \\
\text { between the shop floor staff and the top management team. }\end{array}$ & $\begin{array}{l}\text { - The management team have made vision statement clearer and } \\
\text { accessible for employees. It promoted the establishment of a 'Thinking } \\
\text { together-Acting together' approach, encouraging coordination and } \\
\text { integration between departments and the management team. } \\
\text { - Through the implementation of VPMS, the company identified a set of } \\
\text { balanced KPIs including financial, customer facing, operational and } \\
\text { people development related metrics. } \\
\text { - Regular meetings, involving workers, are set up to review goals and } \\
\text { plans in order to sustain the improvements and establish a continuous } \\
\text { improvement culture. } \\
\text { - Shop floor staff is now more engaged with the management team and } \\
\text { involved in the idea generation and company-wide decision making } \\
\text { process. } \\
\text { - The management team decided to adopt an 'open door' policy to listen } \\
\text { to new ideas from employees. All that fosters the identification of new } \\
\text { priorities and milestones for the business and, thus, the generation of } \\
\text { new innovative ideas. }\end{array}$ & $\begin{array}{l}\text { The ideas emerging resulted in the } \\
\text { launch of a number of new } \\
\text { products in markets as diverse as } \\
\text { Brazil and USA. At the time of } \\
\text { writing the financial impact of } \\
\text { these new product launches were } \\
\text { not quantified. }\end{array}$ \\
\hline
\end{tabular}




\begin{tabular}{|c|c|c|c|c|c|}
\hline 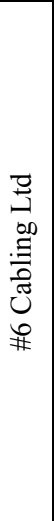 & 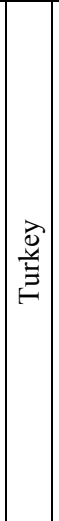 & 250 & $\begin{array}{l}\text { - There is a professional management team and the owners are } \\
\text { detached from business. Strategy planning is informal and the } \\
\text { company employs an ad-hoc approach to develop strategic } \\
\text { projects without linking them towards same strategic direction/ } \\
\text { vision. } \\
\text { - Performance management is based on internal and customer } \\
\text { quality audits, lead times, supplier performance and financial } \\
\text { performance. } \\
\text { - Company values different ideas and therefore there is a } \\
\text { collaborative and open communication among the management } \\
\text { team members. However, potential conflict exists with company } \\
\text { core staff and contract staff and it is difficult to get changes } \\
\text { implemented effectively in the organisation. }\end{array}$ & $\begin{array}{l}\text { - The main impact of VPMS implementation was the internalisation of } \\
\text { the 'vision - strategy - projects' relationship and the alignment of } \\
\text { improvement projects with the business goals. The system promotes a } \\
\text { deeper awareness of the key improvement projects in the firm and } \\
\text { provides support in sustaining change in the company. VPMS } \\
\text { facilitated the launch of two innovation projects that resulted in lead } \\
\text { time reduction and increased competitiveness. } \\
\text { - Performance metrics are not changed however the company is more } \\
\text { able to interpret the linkages between the KPIs and the impact on } \\
\text { overall business performance. } \\
\text { - The company uses the VPMS boards to communicate strategy and } \\
\text { progress within the management team as well as with employees. } \\
\text { - VPMS facilitated a common understanding of business priorities and } \\
\text { responsibilities. }\end{array}$ & $\begin{array}{l}\text { Incremental improvement of } \\
\text { productivity and turnover as a } \\
\text { result of more purposeful and } \\
\text { better focused continuous } \\
\text { improvement programmes that } \\
\text { delivered better products and } \\
\text { services to their existing customer } \\
\text { base. }\end{array}$ \\
\hline 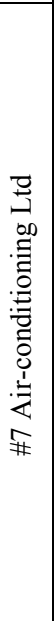 & 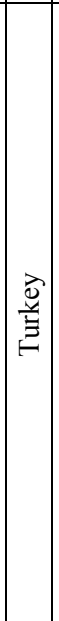 & 246 & $\begin{array}{l}\text { - There is an overly complex and written strategy document. The } \\
\text { strategy process is not very effective regarding implementation } \\
\text { and review as the review cycles take months rather than days. } \\
\text { - Performance management is based on KPIs measuring weekly } \\
\text { production speed, delivery performance, monthly profit/loss } \\
\text { accounts, net assets, customer satisfaction surveys and customer } \\
\text { complaints. } \\
\text { - Communications are mainly based on day to day conversations. } \\
\text { The communication with shop floor staff is not very effective as } \\
\text { their ideas for improvement are not captured. }\end{array}$ & $\begin{array}{l}\text { - The main impact of VPMS implementation was having a clear 'big } \\
\text { picture' of the whole company. The company adopted the visual boards } \\
\text { and created their own versions making them more relevant to their } \\
\text { business. The system facilitated the identification of bottlenecks and } \\
\text { strength areas. } \\
\text { - VPMS approach significantly reduced the strategic planning and } \\
\text { performance review time. Performance metrics were revised and only } \\
\text { the most relevant KPIs were implemented. The new approach was seen } \\
\text { more effortless and dynamic in the context of fast changes in the } \\
\text { business environment. As a result the company has improved their } \\
\text { responsiveness to customer demand. } \\
\text { - The company is a large SME and therefore communications and } \\
\text { updates on the visual boards were seen particularly challenging. } \\
\text { Especially ownership and updating of the boards across multiple sites } \\
\text { was a concern } \\
\text { - The system has enabled management team empowerment and } \\
\text { coordination as it enhanced visibility in the company. }\end{array}$ & $\begin{array}{l}\text { As the company already had a } \\
30 \% \text { market share the main } \\
\text { financial impact of the VPMS was } \\
\text { in incremental productivity } \\
\text { improvements. } \\
\text { In addition, the company reduced } \\
\text { its strategy review and response } \\
\text { cycle from three months to four } \\
\text { weeks thus enabling to react to } \\
\text { significant changes in its } \\
\text { environment faster. It is now } \\
\text { confident that it will be able to } \\
\text { respond to market opportunities } \\
\text { and threats faster than its } \\
\text { competitors. }\end{array}$ \\
\hline
\end{tabular}


Table 4: Cross case analysis.

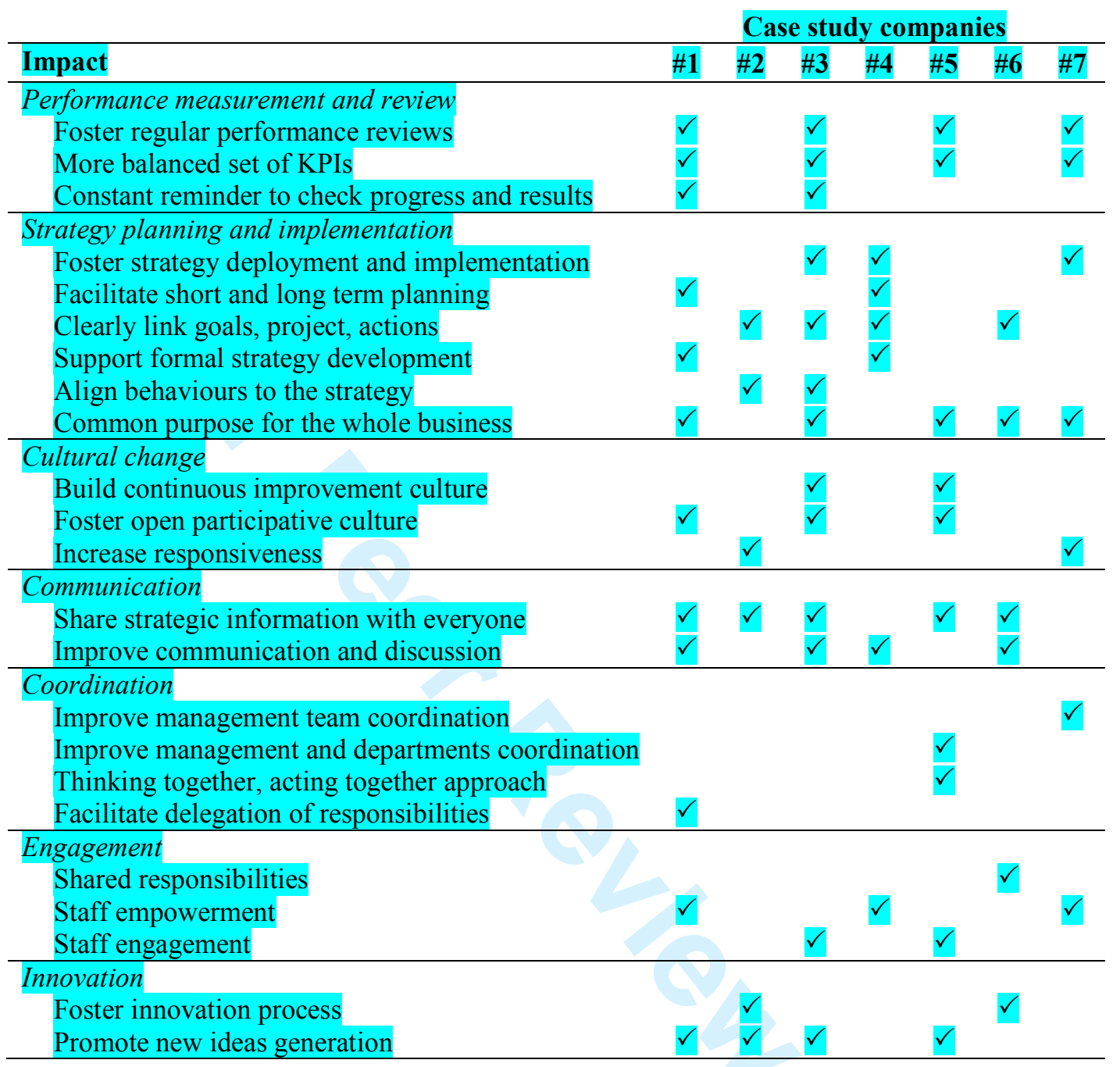


Figure 1: The conceptual model.

Figure 2: Research process.

Figure 3: Example of influence map development.

Figure 4: Bottling Ltd strategic planning board.

Figure 5: Bottling Ltd strategic progress board.

Figure 6: Bottling Ltd operational progress board.

Figure 7: Entertainment Ltd strategic planning board.

Figure 8: Entertainment Ltd strategic progress board.

Figure 9: Entertainment Ltd operational planning board.

Figure 10: Entertainment Ltd operational progress board.

Figure 11: The impact of the visual performance management system. 
- Deployment of strategic objectives to value streams, processes, teams and individuals

- Use of effective performance measures

- Focusing on improvement and growth actions

- Continuous review

- Adaptation to the changing environment

- Rapid response to significant events

- Effective two-way communication

- Formal and informal dialogue between managers and staff

- Linking routine jobs and tasks to the purpose and strategy of the organisation

- On-the-job education of people

\section{Could enhance/improve...}

- Information quality

- Shared understanding and ownership

- Communication and coordination between people, functions and departments, breaking down of organisational boundaries

- Transparency and openness of the work environment

- People involvement, motivation and engagement

- Targeting of continuous improvement

- Decision making and confidence at all levels 
Figure 2: Research process. $254 \times 88 \mathrm{~mm}(150 \times 150 \mathrm{DPI})$ 


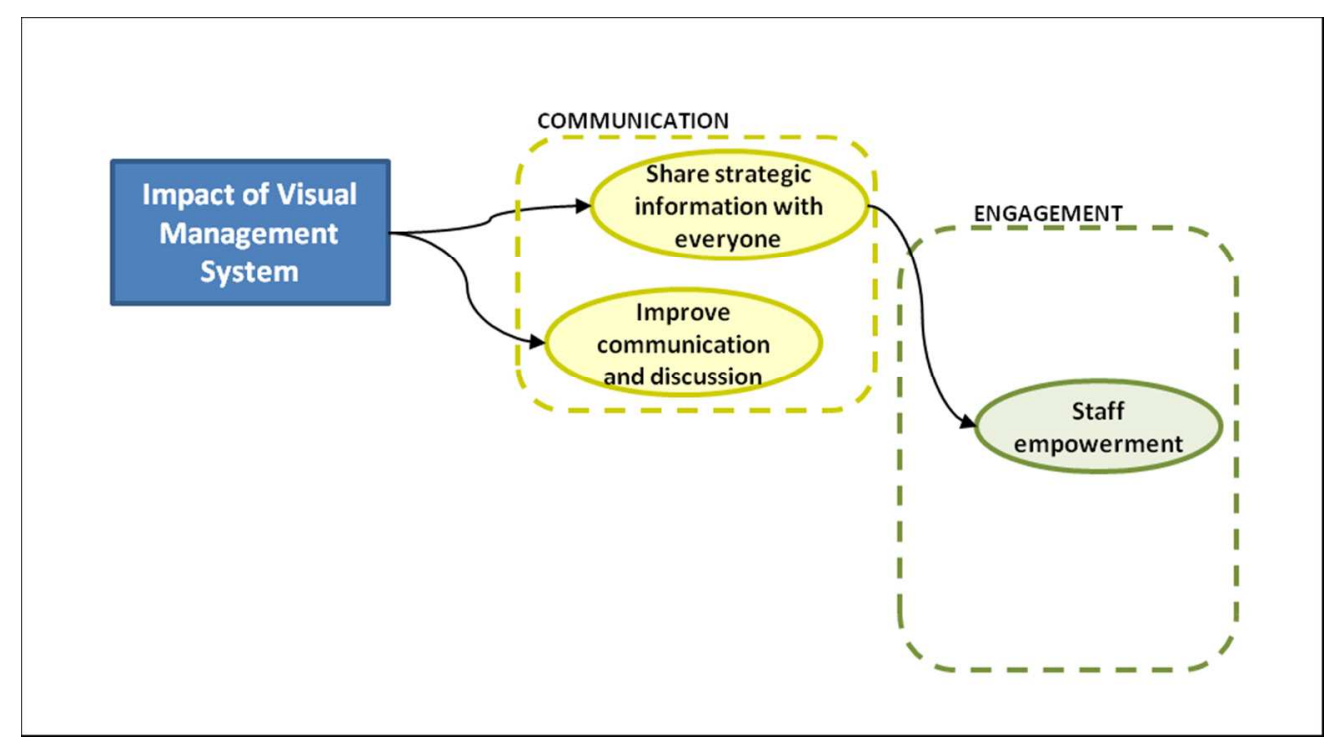

Figure 3: Example of influence map development. $170 \times 94 \mathrm{~mm}(150 \times 150 \mathrm{DPI})$ 


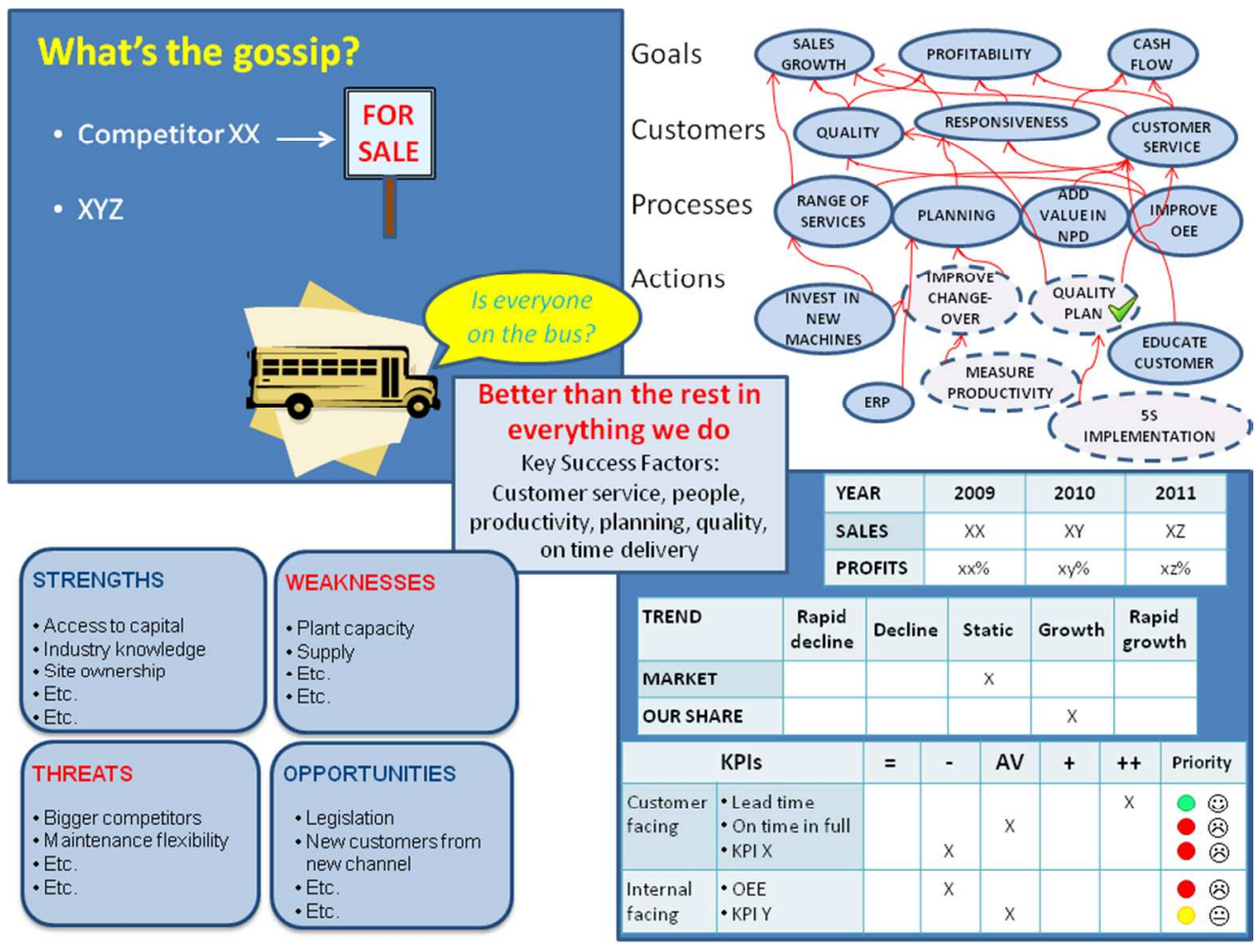

Figure 4: Bottling Ltd strategic planning board. $254 \times 190 \mathrm{~mm}(96 \times 96$ DPI) 


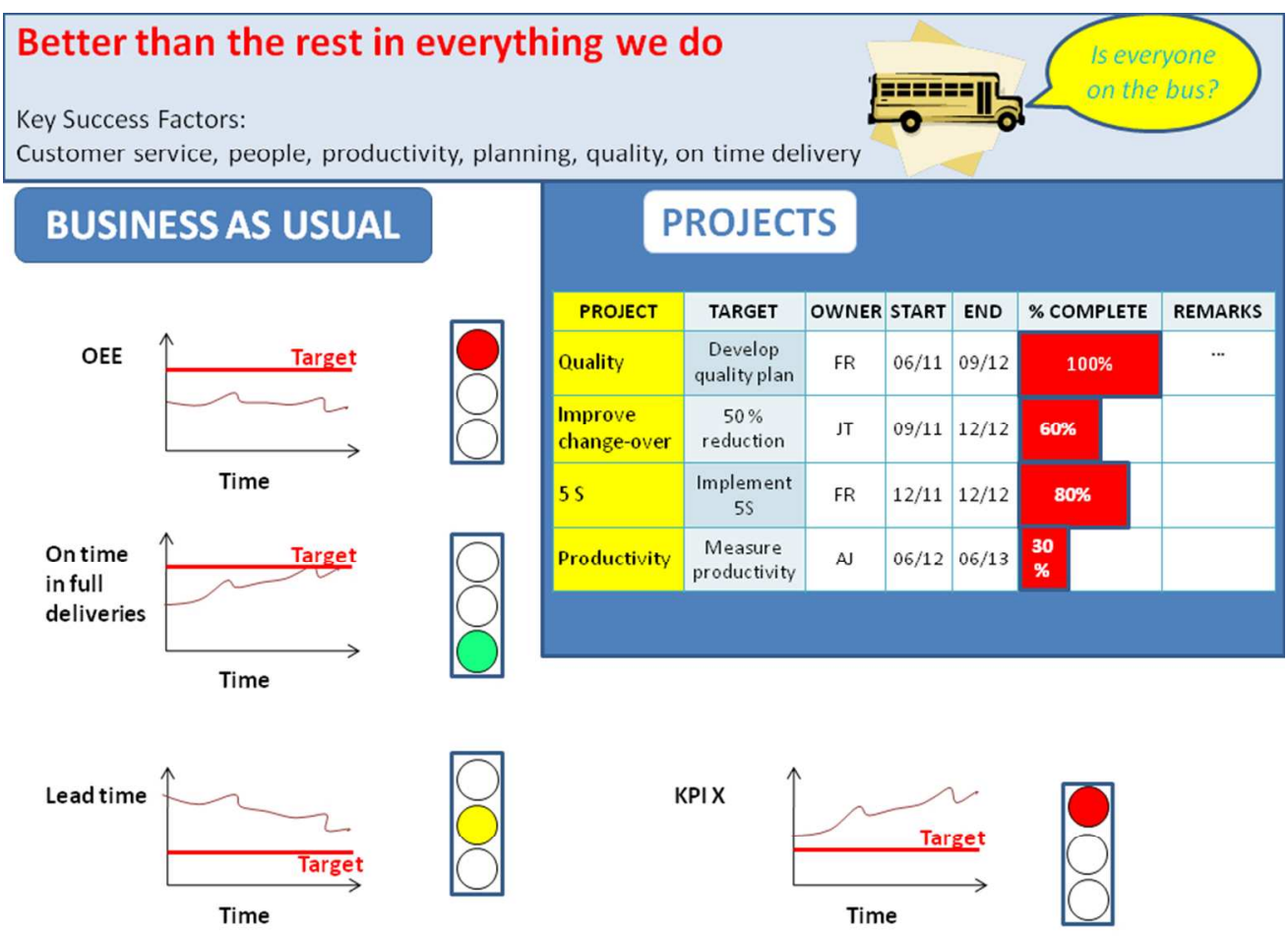

Figure 5: Bottling Ltd strategic progress board. $254 \times 190 \mathrm{~mm}(96 \times 96 \mathrm{DPI})$ 


\section{COMMUNICATION}

- New machine arriving in November

- Last quarter objectives met! Well done!

- What do you think important to measure in your work area? Give us your comments!

- First results of 55 project:

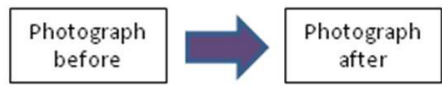

\section{CUSTOMER COMPLAINTS A3 REPORT}

\begin{tabular}{|l|l|}
\hline COMPLAINT & Torn labels on bottles \\
\hline $\begin{array}{l}\text { CONSEQUENCES FOR } \\
\text { CUSTOMER }\end{array}$ & Customer cannot sell the bottles \\
\hline CAUSES & $\begin{array}{l}\cdot \text { Cases too tight } \\
\cdot \text { Poor packing technique }\end{array}$ \\
\hline CORRECTIVE ACTIONS & $\begin{array}{l}\cdot \text { Re-design case } \\
\cdot \text { Re-train packaging operators }\end{array}$ \\
\hline
\end{tabular}

Figure 6: Bottling Ltd operational progress board. $190 \times 254 \mathrm{~mm}(96 \times 96 \mathrm{DPI})$ 
Figure 7: Entertainment Ltd strategic planning board. $254 \times 190 \mathrm{~mm}(96 \times 96 \mathrm{DPI})$ 


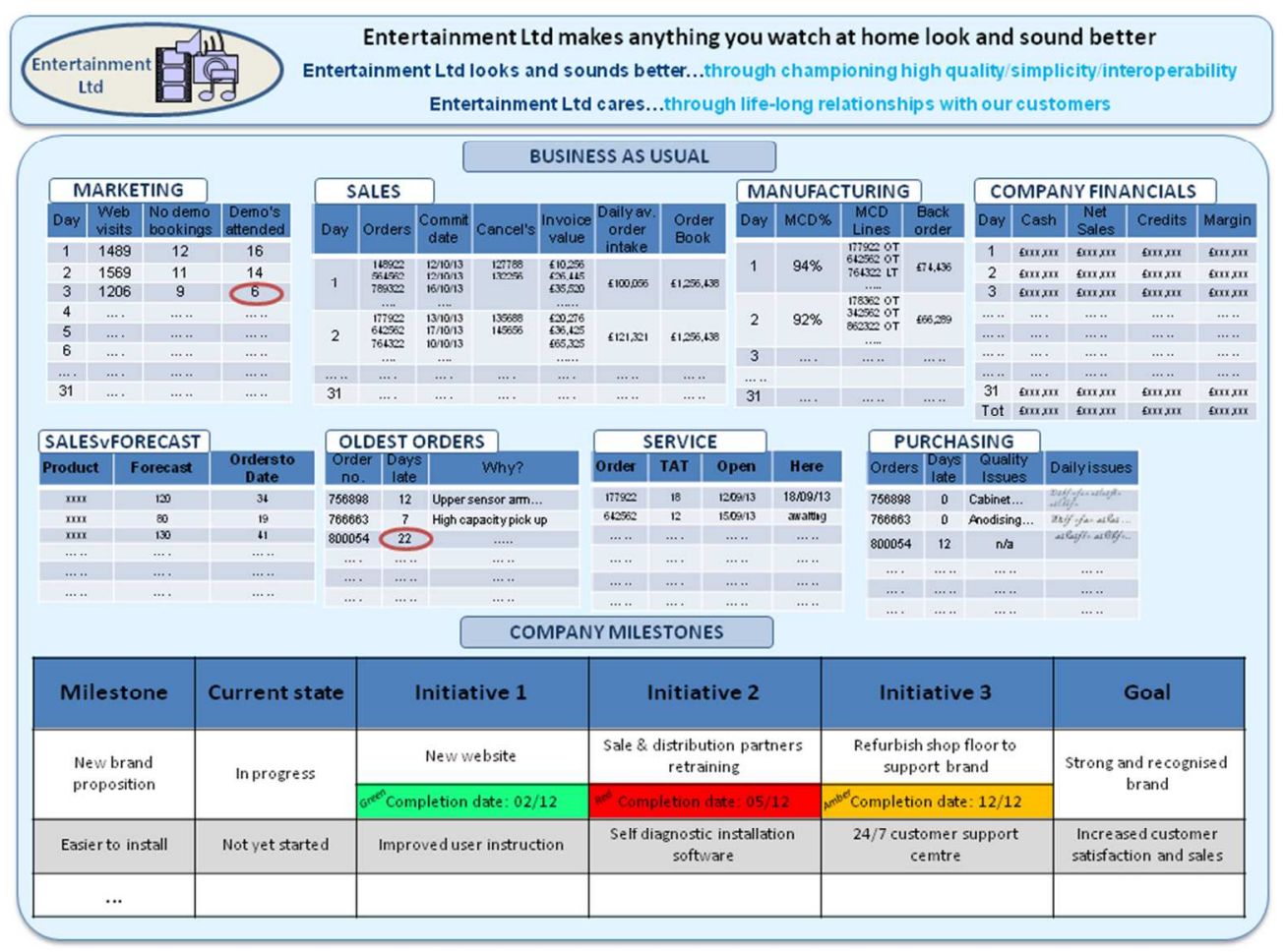

Figure 8: Entertainment Ltd strategic progress board. $254 \times 190 \mathrm{~mm}(96 \times 96 \mathrm{DPI})$ 


\section{ENTERTAINMENT LTD VISION}

Entertainment Ltd makes anything you you watch at home look and sound better

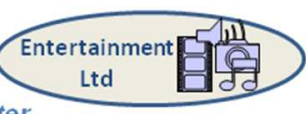

\section{MANUFACTURING OPERATIONS MISSION:}

Create a manufacturing and service organ isation based around agreed principles, beh aviours and empowered emplovees th at is real-time and lean and committed to continu ously improving the products and services th at we offer our customers
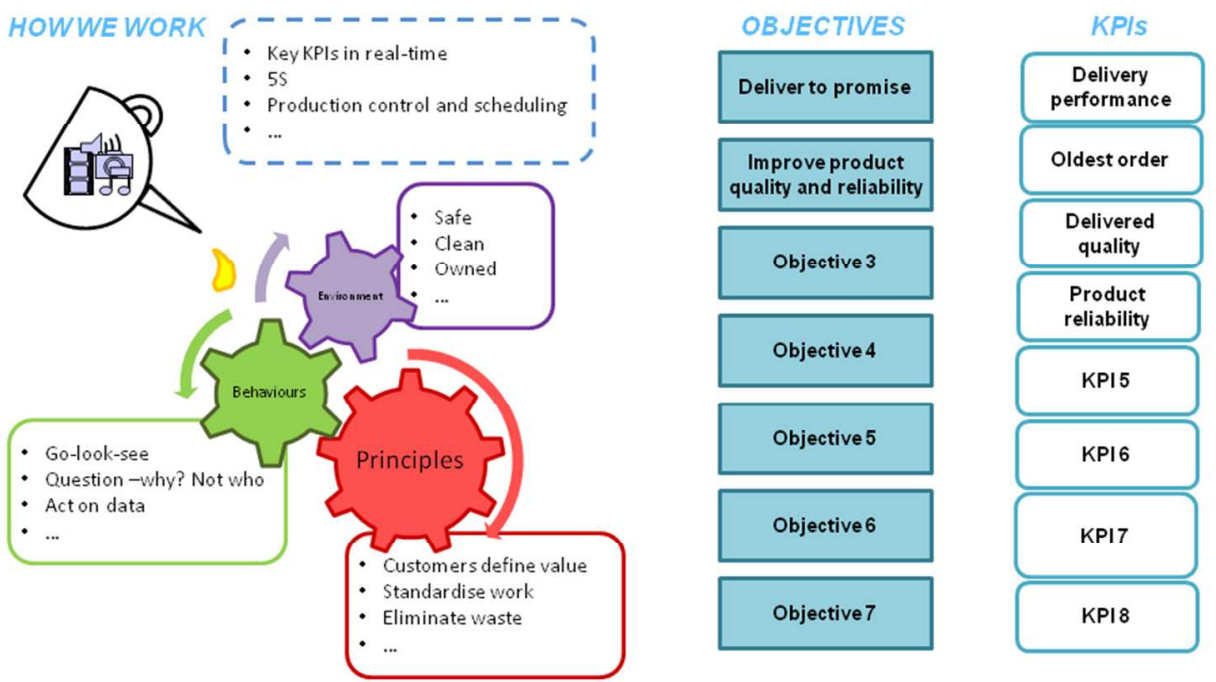

Figure 9: Entertainment Ltd operational planning board. $254 \times 190 \mathrm{~mm}(96 \times 96 \mathrm{DPI})$ 

MANUFACTURING OPERATIONS MISSION:

Create a manufacturing and service organ isation based around agreed principles, behaviours and empowered emplovees that is real-time and lean and committed to continu ously improving the products and services that we offer our customers

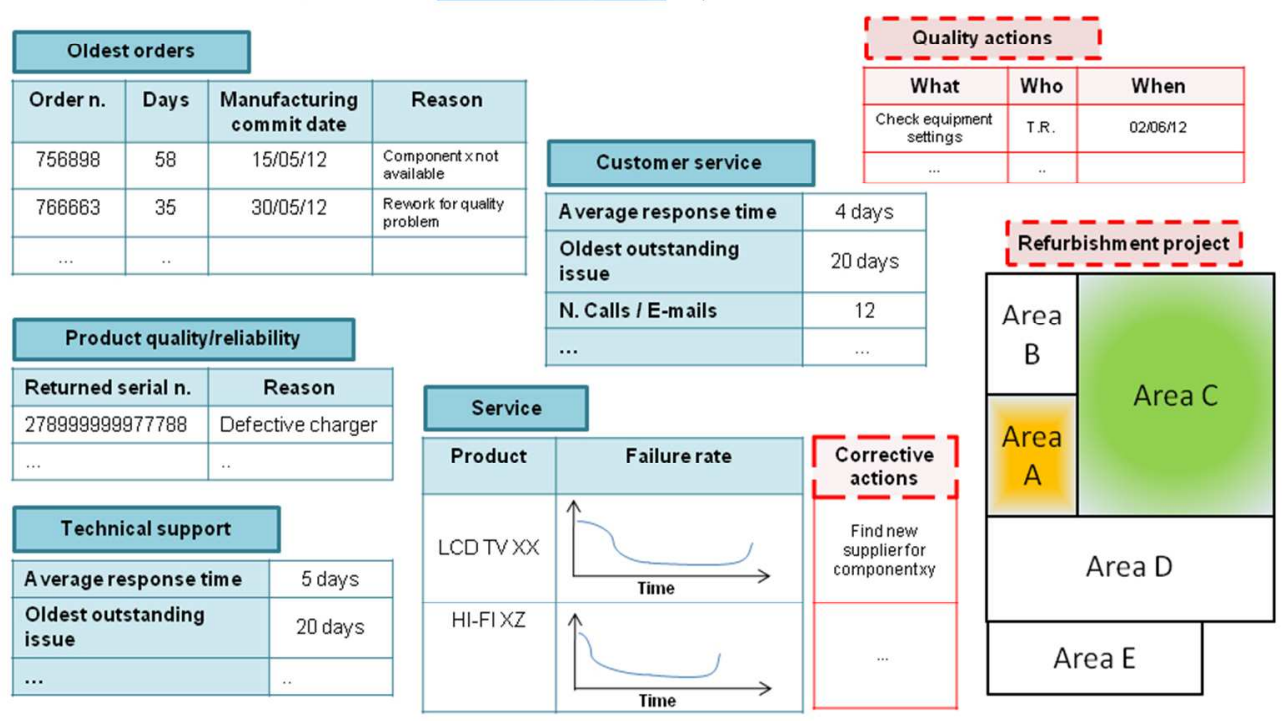

Figure 10: Entertainment Ltd operational progress board. $254 \times 190 \mathrm{~mm}(96 \times 96 \mathrm{DPI})$ 


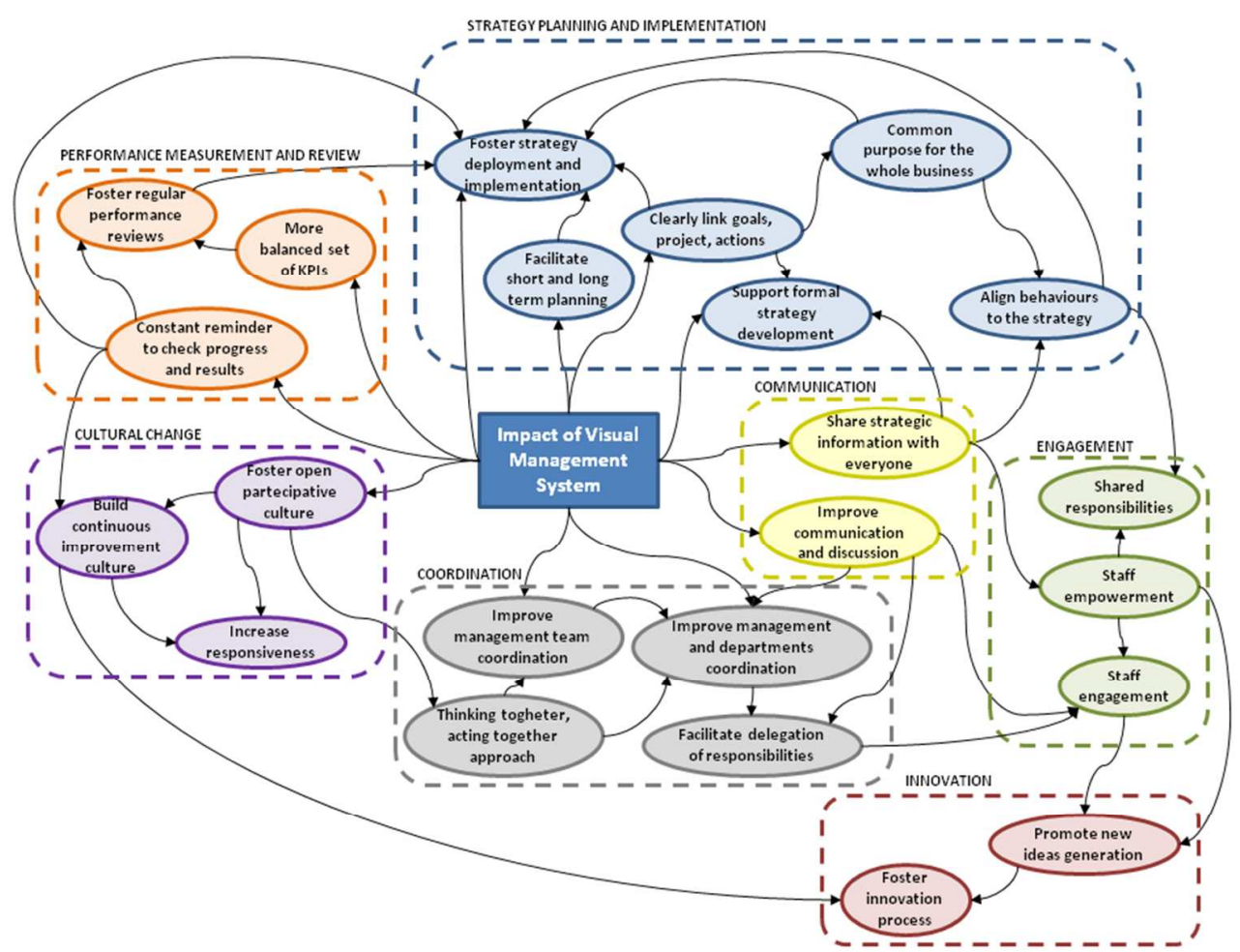

Figure 11: The impact of the visual performance management system. $254 \times 190 \mathrm{~mm}(96 \times 96 \mathrm{DPI})$ 